\title{
REVEALING THE GENDER INEQUALITY IN PATRICIA MC. CORMICK'S SOLD: CRITICAL DISCOURSE ANALYSIS
}

\author{
Ririn Fatmawati \\ Jember University \\ ririnfatma88@gmail.com \\ Sukarno \\ Jember University \\ msukarno08@gmail.com \\ Ikwan Setiawan \\ Jember University \\ senandungtimur@gmail.com
}

\begin{abstract}
ABTRACT
This study aims to reveal the gender inequality between male and female in the novel entitled Sold. It is the representation of Nepalese culture in social life. The data source is the novel of Sold. The data in this study take the form of words, phrases, and sentences found in the Sold, which contain gender inequality. Critical discourse analysis proposed by Van Dijk's theory is applied in this study. The result of this study shows that males tend to dominate over females. Male sportray their irresponsibility to their own family. Moreover, women have limited decision powers. They areburdened by their husbands and they do not have the rights to choose due to cultural or religious factors.
\end{abstract}

Keywords: Gender inequality, critical discourse analysis, Sold, domination.

\begin{abstract}
ABSTRAK
Penelitian ini bertujuan untuk menjelaskan ketidaksetaran gender antara laki-laki dan perempuan dalam novel yang berjudul Sold. nobel ini mewakili kebudayaan negara Nepal dalam kehidupan sehari-hari. Sumber data dalam penelitian ini diamabil dari novel Sold. data dalam penelitian ini adalah katakata, frasa, dan kalimat-kalimat yang mengandung ketidaksetaraan gender yang ada dalam novel Sold. Penelitian ini menggunakan teori analisis wacana kritis yang ditulis oleh Van Dijk. Hasil dalam penelitian ini menunjukkan bahwa laki-laki cenderung mendominasi perempuan. Laki-laki menunjukkan bahwa mereka tidak bertangung jawab terhadap keluarga. Sedangkan para wanita tidak memiliki hak dalam mengambil sebuah keputusan. Mereka akan terbebani oleh suami mereka dan mereka tidak memiliki hak untuk memilih dikarenakan faktor budaya dan agama.
\end{abstract}

Kata kunci: Ketidaksetaraan gender, analisis wacana kritis, sold, dominasi. 


\section{INTRODUCTION}

Equality is one of the important things in life. It is one of the objectives of the United Nations Universal Declaration of Human Rights, which seeks to create equality in law and in social situation such as democratic activities and securing equal pay for equal work. Both men and women should receive equal treatment and not be discriminated based on their gender. Mackin (2014, p.12) states that male and female haveto get the same right in terms of education, politic, and economic in achieving sustainable development country.

There are many inqualities occuringin a social practice, such as women as victims of sexual offences or rape, physical abuse by husbands, polygamy, physical and psychological harassment by household members. Some examples above show that male is always dominant over female. It links with Murphy's statement (2004, p.25) that sex-role stereotypes say that men should be dominant; achieving and enacting a dominant role in relations with others is often taken as an indicator of success.

Gender inequality does not only happen in the family environment, but it also happens in a leadership and political participant. 22 percent of legislators, senior officials, and managers are women, further only 18 percent of the seats in the House of Representatives are held by women (Anderson, 2015, p.1).Based on the assertion above, the male is dominanttowards female in economic and political life.

In addition, gender inequality exists in education. It occurs because cultural norms may also be a factor causing sex discrimination in education. For example, society suggests that women should be mothers and be responsible for the bulk of child-rearing. Therefore, women feel compelled to pursue educational pathways that lead to occupations that allow for long leaves of absence, so they can stay at home mothers. It deals with the slogan of "husbands are the breadwinners and wives take care of things at home (Agrawal, 2015, 2).

The source of data in this article is Sold. Itis a novel by Patricia McCormick, published in 2006. It tells the story of a girl from Nepal named Laksmi, who is sold into sexual slavery in India. This study describes about how gender inequality can be revealed through linguistics data and the contextual background that supports in the novel. The novel is written in a series of short, vignette-style chapters. There are 181 chapters in the novel, but this study will analyse 25 chapters, which describes gender inequality through sentences, phrases, clauses.

\section{THEORY AND METHOD}

Van Dijk's theory is commonly known as sociocognitive. It is the combination of dimensions that consists of three-dimensional concept. 
Those are social situation, cognition, and text. Further, it will be described in the sociocognitive diagram below;

Diagram 1: Sociocognitive diagram

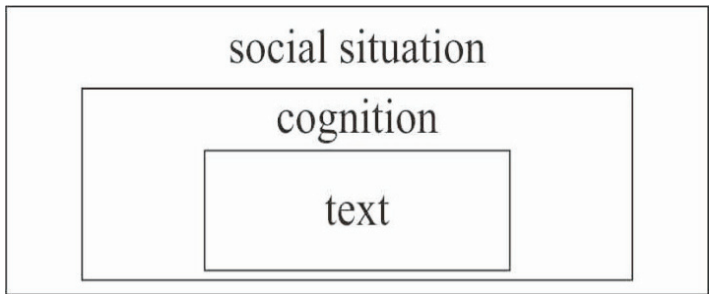

The first dimension is called social situation. The notion of social situation implies social representationof power, domination and social inequality among groups, organizations and institutions. Van Dijk (2001, p.32) defined that CDA also needs to account for the various forms of social cognition that are shared by these social collectivities: knowledge, attitudes, ideologies, norms and values. These representations control the production of discourse, text and talk, and they may be expressed directly and indirectly.

The second dimension is cognition. It is a mental representation of a certain group of people. Van dijk (2009, p.16) views that discourse does not only focus on discourse structure, but also how the text is reproduced by a certain group or people. The production and comphrehension of discourse are controlled by context model. It is based on the knowledge and ideologies of the listeners or readers. Discourse controls the fact that people understand and represent not only text and talk, but also communicative situation.

The third dimensions of Van Dijk's theory is text. The language of text is the main part of controlling people's mind by analysing the words, verb, sentence, proposition, clause and phrase used in the discourse to express the implisit meaning of the text. Supporting the assertion above, Van Dijk (2001: p. 354) views that the text consists of many elements. The first one is macrostructure. It is a global meaning of text that can be observed by seeing the theme of discourse. The second element issuper structure of discourse, the meaning of discourse that can be analyzed from the small part of discourse; those are sentence, proposition, subordinate clause, paraphrase, and picture.

It can be infered that discourse consists of three elements, includingmacro structure (global meaning), super structure (discourse framework), and microstructure (semantics, syntax, stylistics). The table below describesthe three elements of discourse breifly based on Van Dijk's theory. 
Tabel 1. Three elements of discourse based on Van Dijk's model

\begin{tabular}{|c|c|c|}
\hline $\begin{array}{l}\text { Discourse } \\
\text { Structure }\end{array}$ & Explanation & $\begin{array}{l}\text { Element of } \\
\text { Discourse }\end{array}$ \\
\hline Macrostructures & $\begin{array}{l}\text { Thematic } \\
\text { Global meaning of the text that can be analysed } \\
\text { by seeing the theme/topic as a representation the } \\
\text { idea of the text. }\end{array}$ & Topic \\
\hline Superstructures & $\begin{array}{l}\text { Schematic } \\
\text { Schematic describes about how discourse } \\
\text { structure of the text. It is related to framework of } \\
\text { the text such in the novel. }\end{array}$ & $\begin{array}{l}\text { Schema } \\
\text { Introduction, } \\
\text { problems, } \\
\text { solutions. }\end{array}$ \\
\hline \multirow[t]{3}{*}{ Microstructures } & $\begin{array}{l}\text { Semantic } \\
\text { The meaning of the text that is expressed by the } \\
\text { author. }\end{array}$ & $\begin{array}{l}\text { Settings, } \\
\text { detail, meant, } \\
\text { presupposition. }\end{array}$ \\
\hline & $\begin{array}{l}\text { Syntax } \\
\text { Type of sentences that are used in the novel. }\end{array}$ & $\begin{array}{l}\text { Type of } \\
\text { sentences, } \\
\text { coherence, and } \\
\text { cohesion }\end{array}$ \\
\hline & $\begin{array}{l}\text { Stylistic } \\
\text { Diction (an exact words that has been used in the } \\
\text { text) }\end{array}$ & Lexicon \\
\hline
\end{tabular}

Type of research in this study is library research. It is a research to use nonexperimental design.Data cannot be easily quantified and the analysis is interpretative (descriptive) (Macky \& Gass, 2005: p. 2). Qualitative data are used in this research. The data in this study are in the forms of words, phrases, sentences found in the Sold, which containgender inequality. It deals with Blaxter, Hughes, Tight (2006: p. 60) qualitative research, on the other hand, is concerned with collecting and analyzing information in as many forms, chiefly non-numeric, as possible. It is only to analyze the data in the shape of information through the phrase, sentence, and words, which show gender inequality.
The data in this study are collected through documentation techniques. It means that the data are taken from document and internet browsing. Data are not obtained from the field such as by doing interview or giving questionnaires to informant or to respondent. Blexter et al (2006, p. 187) mentions that documentary (bibliographical) study proceeds by abstracting from each document, that element which may consider to be important or relevant, by grouping together those findings, or settings them alongside other which we believe to be related.The techniques of analyzing in this research are descriptive method and interpretative method. Descriptive method is a method to take description, illustration, explanation, accurately and 
systematically. In addition, As Blaxter, Hughes, Tight (2006, p.219) mentioned; interpretation is the process by which you put your own meaning on the data you have collected. In this research, I interpret the data to see gender inequality through phrases, clauses, sentences in the Sold, which will be analyzed by Van Dijk's theory.

\section{FINDING AND DISCUSSION}

The discussion of the research describes about gender inequality based on the text, the cognition of Nepalese, and social situation. The first discussion is text analysis. There are three main parts of text analysis. They are microstructure, superstructure, and macrostructure. The second one is the cognition. It is a mental representation. There are two kinds of way sof thinking in the novel as a representation of Nepalese. Those are giving a dowry and sons preference. The third discussion is about the social situation. It relates to social culture in Nepal containing of gender inequalities in term of behaviour and harrasment. The details will be explained below.

\section{Gender Inequality Based on the Text}

The language of text is the main part of controlling people's mind by analysing the words, verb, sentence, proposition, clause and phrase used in the discourse to express the implisit meaning of the text. This study reveals about gender inquality through sentences in the novel containing gender inequality. There are three main parts of the text analysis that is used by Van Dijk's theory. They are microstructure, macrostructure, superstructure. The detail explanation about three elements parts of text will be revealed in the following.

\section{Microstructures}

The first element of microstructure analysis is syntax. This research provides some data divided to verb, phrase, noun, and adjective containing gender inequality between male and female in the novel.It is classified in the table 1 . The first classification is tht the verbs found in the novel. They figure out that female is always a victim of gender inequlity in social practice while male is always dominant over female. It can be infered by analysing verbs that used by male characters such as; dragging, rape, cheat, hunt, beat, squint, play card. Those verbs belong to action verb. They express physical or mental actions, which affect suffering of female. The verbs of sell and play belong to action verb. They emphasizethat male is always happy and fun with his own life. It is described by Lakshmi's stepfather as the picture of Nepalese male in a rural region.

The second classification based on data source is phrase. There are four phrases addressed for female. They are; climb high up the mountain, take food, feed it to the children, andsilence their own charming stomach. All phrases above are obvious that Lakshmi and Ama as female characters must sacrifice their life for family members' needs. They 
mustfight against their own suffering themselves by climbing mountain for getting wood, serving their children by feeding them and take food for Ama's husband. Another phrase is no part of me unmarked by strap. It is the picture of Lakshmi, who accepts Mumtaz's torture whenever she does not want to serve customer properly. In contrast, male characters show their power by stating some phrases such as putyou back in the locked room, use a privy, cover your face and head with your shawl. The phrases above imply cultural social practices, which exist in Nepal. They have implisit meaning to control female through that kind of rules, which are cumpolsory in practice.Other phrasesare sell earings, wearing his kingly head. They point out Lakshmi's stepfather enjoy his life on his family's bad condition by asking her wife to sell her earing then spend the money for himself. The phrase of wearing his kingly head describes his performance how he does not care for his family at all.

The third classification consisting gender inequality can be observed from the noun that is used by male and female characters. Female character has accepted all behavior, which shows unequal treatment towards herself. The nouns used in the novel arehurt, pain, sold, and maid. McCormick applies them to describe how suffering of Lakshmi staying in the brothel by accepting physical abusefrom the pimp of the happiness house. Additionally, McCormick uses the nouns of honor and gambler to describe male characters. They are praised and honored, even though they do negative way. It is influenced by cultural norms that husband is god. As a result, they have to obey and do every husband's word.

The forth classification consisting gender inequality is adjective. Some adjectivesare addressed towards female. Those are burning, aching, and naked. It describes obviously that female obtain physical abusefrom their partner if they do not agree with husband's instruction. Drunken belongs to adjectives which describes the personality of male. It is roled by Lakshmi's stepfather as the image of Nepal people in term of gender inequality. The following classificasion part of speech list is provided to perceive the research easily.

Tabel 2. The classification of part of speech containing gender inequality

\begin{tabular}{|l|l|l|}
\hline \multirow{2}{*}{ Part of speech } & \multicolumn{1}{|c|}{ Gender inequality } \\
\cline { 2 - 3 } & \multicolumn{1}{|c|}{ Female } & \multicolumn{1}{|c|}{ Male } \\
\hline Verb & Crying, pay, suffer, work, collapse, & $\begin{array}{l}\text { Dragging, sell, rape, cheat, hunt, } \\
\text { beat, squint, play card, }\end{array}$ \\
\hline Phrase & $\begin{array}{l}\text { Climb high up the mountain. } \\
\text { Take food, feed it to the children, } \\
\text { and silence their own charming } \\
\text { stomach. } \\
\text { No part of me unmarked by strap. } \\
\text { Eat your meal only after your } \\
\text { husband has had fill it. }\end{array}$ & $\begin{array}{l}\text { Sell earings, wearing his kingly } \\
\text { head. } \\
\text { Put you back in the locked room } \\
\text { head with your shawl. }\end{array}$ \\
\hline
\end{tabular}


Ririn Fatmawati, Sukarno, Ikwan Setiawan - Revealing the Gender Inquality...

\begin{tabular}{|l|l|l|}
\hline Noun & hurt, pain, sold, maid & Honor, gambler \\
\hline Adjective & Burning, aching, naked, & Drunken \\
\hline
\end{tabular}

The second element of microstructures analysis isstylistics. This element explains that the meaning of discourse can be defined through lexicon or word choice to catch the implisit and explisit meaning in the novel. McCormick uses a conotation to represent of something, which makes the language more polite. Chandler (2002, p.5) states that the term of connotation is used to refer to the sociocultural and personal associations (ideological, emotional etc) of the sign. These aretypically related to the interpreter's class, age, gender, and ethnicity. The conotation, which is used in the novel containing gender inequality and poverty, will be shown below.

\section{Datum $2 \quad A$ tin roof means that} the family has a father who doesn't gamble away th e landlord's money playing cards in the tea shop. A tin roof means the family has a son working at the brick kiln in the city. $A$ tin roof means that when the rains come, the fire stays lit and the baby stays healthy.
Datum 24 I understand slowly, then all at once, that my stepfather has taken my cucumbers to Bajai Sita, the old trader woman, and sold them. I understand, too, why his cot is empty.

The word of $A$ Tin roof in datum 2 is symbolized of the home of Lakshmi's family which is very bad condition. It is a place where every problem happens and the only one place they have to protect all family members from any seasons. The word of cucumbers in datum 24 explains the only one thing she has in the family. It represents how poor Lakshmi's family because cucumbers belong to cheap things. McCormick attracts the readers to know more about Nepalese who live in a rural area.

\section{Superstructures}

The second element on text analysis is superstructure. It is correlated with schema. The schema of the novel consists of beginning, inciting incident motivating force, complications, climax, anticlimax, and conclusion. The schema of the novel will be described in the following table. 
Table 3. The schema of the novel

\begin{tabular}{|c|c|c|c|}
\hline $\begin{array}{l}\text { The Novel } \\
\text { Schema }\end{array}$ & Description & Data & Text \\
\hline Beginning & $\begin{array}{l}\text { Setting is } \\
\text { established, } \\
\text { characters are } \\
\text { introduced, } \\
\text { problem of } \\
\text { the story is } \\
\text { introduced }\end{array}$ & $\begin{array}{c} \\
4 \\
3 \\
4\end{array}$ & $\begin{array}{l}\text { One more rainy season and our roof will be } \\
\text { gone, says Ama. } \\
\text { Tin roof means that the family has a father wo } \\
\text { doesn't gamble away the land lord's money } \\
\text { playing cards in the tea shop. A tin roof means } \\
\text { the family has a son working at the brick kiln } \\
\text { in the city. A tin roof means that when the } \\
\text { rains come, the fire stays lit and the baby stays } \\
\text { healthy. } \\
\text { Let me go to the city, "I say." } \\
\text { I can work for a rich family like Gita does, and } \\
\text { send my wages home to you. }\end{array}$ \\
\hline $\begin{array}{l}\text { Inciting insident } \\
\text { motivating } \\
\text { force. }\end{array}$ & $\begin{array}{l}\text { Some event } \\
\text { gets story } \\
\text { really rolling }\end{array}$ & 26 & $\begin{array}{l}\text { Ama wipes her cheek with the hem of her } \\
\text { shawl," Your stepfather has said that you must } \\
\text { go to the city and earn your keep as a maid". } \\
\text { You Belong to me," she says." And I paid a pretty } \\
\text { sum for you too. She opens to the page in her } \\
\text { book points to the notation for } 10.000 \text { rupees. }\end{array}$ \\
\hline Complications & $\begin{array}{l}\text { Events that } \\
\text { make the } \\
\text { solution to the } \\
\text { problem more } \\
\text { challenging }\end{array}$ & $\begin{array}{l}34 \\
35 \\
36\end{array}$ & $\begin{array}{l}\text { Then Mumtaz flies at me, she grabs me by the } \\
\text { hair and drags me across the room. } \\
\text { She flings me onto the bed next to the old man. } \\
\text { And then he is on the top of me, holding me } \\
\text { down with the strength men. } \\
\text { He kisses me with lips that are slack and wet } \\
\text { and taste of onions. } \\
\text { His teeth dig into my lower lip. }\end{array}$ \\
\hline
\end{tabular}




\begin{tabular}{|c|c|c|c|}
\hline Climax & $\begin{array}{l}\text { The greatest of } \\
\text { difficulty and } \\
\text { the solution } \\
\text { of the major } \\
\text { problem }\end{array}$ & 46 & $\begin{array}{l}\text { I cry out and try to break free, but shahanna } \\
\text { has hold on me. } \\
\text { Mumtaz draws back, the jaw of the scissors } \\
\text { poised at my neck. } \\
\text { Each morning and evening Mumtaz comes, } \\
\text { beats me with a leather strap, and locks the } \\
\text { door behind her. } \\
\text { Tonights, when Mumtaz comes and unlocks the } \\
\text { door, she sees there is no part of me unmarked } \\
\text { by her strap. }\end{array}$ \\
\hline Anticlimax & $\begin{array}{l}\text { Going to } \\
\text { the most } \\
\text { important } \\
\text { event (climax) } \\
\text { to the } \\
\text { conclusion. }\end{array}$ & 63 & $\begin{array}{l}\text { He is too friendly, the pink American man. } \\
\text { He grips my hand in greeting, a strange and } \\
\text { uncouth gesture that makes me pull back in } \\
\text { alarm. }\end{array}$ \\
\hline Conclusion & The ending & 66 & $\begin{array}{l}\text { I see other men, Indian men. My American is } \\
\text { with them. } \\
\text { 'My name is Lakshmi,' I say. } \\
\text { 'I am from Nepal. } \\
\text { I am fourteen years old. }\end{array}$ \\
\hline
\end{tabular}

Data 1 to 4 are the beginning of the story. This relates to setting where the story is established, characters are introduced, problem of the story is introduced. McCormick introduces the condition of Lakshmi's family by describing how bad their house is in the rainy season. There is nothing left anymore while hard rain comes. She also introduces a gambler stepfather, another member family who lives in small hut.

Data 15 and 24 figure out the raise up of the problems. Her stepfather sends her to the city woman by cheating Lakshmi. She says that she will work as a maid in rich family house. It is the first trading of child trafficking by her own family. It is the beginning of Lakshmi's suffering after the city woman sells her to the man who has raped her. It goes worst while Lakshmi has been sold to Mumtaz, a pimp of the brothel.

Data 26 to 42 describe the complication of the novel. It is the event, which makes the solution to the problem more challenging. It starts from Lakshmi's life in the Happiness House. Mumtazexploits her to serve all man who want her body in high price because she is young and virgin. Mumtaz does physical abuse whenever she refuses customer. McCormick explaines the sexual harrasment that happens to Lakshmi Clearly. It is obvious that she reveals in detail about how child abuse, sexual harrasment happens in the novel. She attemps to attract 
readers to be aware about how sexual harrasment accours in the life. Further she influences readers not to believe someone easily in term of getting new job or other promises which is said by new people.

Data 33 to 37 point out the climax of the novel. It is the greatest of difficulty and the solution of the major problem in the story. It starts from the cruelty becomes bad which is done by Mumtaz. She beats Lakshmi everyday because her price is not expensive anymore. She must move to another rooms, which is smaller and dirty. Moreover, she has to share with other prostitutes. McCormick attract the readers intention about how bad the main character faces her life in the brothel.

Datum 63 explaines the anticlimax of novel. It is part of the most important event (climax) to the conclusion. McCormick introduces the white American in the novel as the solution to help Lakshmi out from the Happiness House. The American man comes to Lakshmi to interview her and to know more about the way how she becomes a prostitute in her age. He tells Lakshmi that he will make her free in her life and explains that she does not need to worry about her debt to Mumtaz anymore.

Datum 66 shows the end of the story. It is the arrival of some police officersand American guy in the brothel. They force to get in though the guards of the brothel and do not allow them to meet Lakshmi. She keeps shouting by saying her identity in English, whichis taught by American person. As the result, she is free from the dirty place and get Mumtaz into the prison.

\section{Macrostructure}

The third main part of text is macrostructure. It is a global meaning of text that can be observed by seeing the theme of discourse. It is related to certain topic of a novel. There are four themes, which are found in the novel. Those are poverty, sacrifice, sex trafficking, and domination. It will be explained as follow.

\section{a. Poverty}

Poverty is one of the theme in the novel beside sacrifice, sex trafficking, child abuse, violence, and domination. This is the basic of anycrimes, whichhappen in the novel as Nepal representation. Living in a rural area particularly hilly region is not easy. People mostly rely on agriculture, which depends on the season to have a good harvest from their land. They must wait harvest time to support their daily life. It becomes worst when a huge surge destroys everything. Lakshmi's family is the image of poverty, which is lack of sufficient land. The data below provide the job of female and the situation of Lakshmi's family in their bad condition.

Datum $12 \quad$ In the cold months,
the woman climb high up the
mountain's spine to scavenge 
Ririn Fatmawati, Sukarno, Ikwan Setiawan - Revealing the Gender Inquality...

for firewood.

Datum 18Ama and I must each make twenty trips down the mountain to the village spring, waiting our turn to bring water up to the rice paddy.

The sentence indatum 12, climb high up the mountain's spine to scavenge for firewood describes that Ama and Lakshmi are the representation of female's job in Nepal. They have to climb up the mountain to get firewood for cooking and water sources for watering rice field. Further, they have to face their own suffering themselves, serving their children by feeding them and take food for Ama's husband. Ama does not care for her own pain. She thinks that family member's need is more important than anything is. Another datum can be seen in datum 18, I must each make twenty trips down the mountain to the village spring, waiting our turn to bring water up to the rice paddy.It points out that Ama, lakshmi's mother, has to to take turn with other people for getting water. It proves that living in a rural area is not easy, especially for women.

\section{b. Sacrifice}

The second theme of the novel is sacrifice. It typically means an act of giving up something valued for the sake of something else regarded as more important or worthy (https:// en.oxforddictionaries.com). Sacrifice is crucial thingin any relationship such as family relationship and love relationship. It shows the quality in a relation and a measure how much someone cares for.

This novel tells about child's sacrifice for her family for getting an improvement in their family's life. She has to work for a rich family to earn money for helping them. She expects that her sacrifice will be useful for each family members. Two female characters sacrifice their life. Those are Lakshmi and her mother. The data below will show how Lakshmi and her mother sacrifice their life.

Datum 3 "Let me go to the city, " I say."

Datum 4 I can work for a rich family like Gita does, and send my wages home to you.

Datum 27 If I go, you will have money enough for rice and curds, milk and sugar. Enough for a coat for the baby and a sweater for you.

The data above imply the female's sacrifice, which is done by Lakshmi. It can be seen in data 3,4,27. Those are Let me go to the city, I can work for a rich family like Gita does, If I go you will have money enough for rice and curds, milk and sugar. She attempts to sacrifice herself by going to the city for working. She 
folllows her friend working as a maid, so she can help her mother to complete their needs. She imagines that she is able to make every family members happy. Her intention does not come from internal motivation. Her stepfather forces her to do it through her mother.

\section{c. Child Trafficking}

The third theme of the novel is child trafficking. Nepal is one of country that is trafficked to India. According to UNICEF (2009), approximately 200,000 Nepali girls and women work in brothels. Nepali girls are desirable as prostitutes in India because they are considered more attractive due to their lighter skin color. Further, Nepali virgins are believed to be able to cure AIDS (Wasti, 2011). Trafficking victims are taken in locations within Nepal, from rural areas to the urban centers. Mainly young girls and women are trafficked for sexual exploitation. In addition, a numbers of child trafficking increased because poor, orphaned girls, and young women believe to traffickers' promises to support them financially and their relatives.The novel describes about child trafficking as the picture of Nepals. It is proved in the following data.

Datum 28 My stepfather squints. He takes in the cosly fabric of the woman's dress, the baubles on her ears, the silver bangles on her wrist," one thousand rupees," he says.

Datum 42 You Belong to me," she says." And I paid a pretty sum for you too. She opens to the page in her book points to the notation for 10.000 rupees.

The italic sentence in datum 28 , one thousand rupees expresses that Lakshmi's stepfather sells her deliberately. Her stepfather has taken money from the city lady to fulfill his own happiness. He spends the money in the gambling place. Lakshmi does not realise that she has been sold to rich family. She is shocked when she arrives in a big house. She feels that she is lucky girl because she is able to use all facilities after her job is done. The day after, she has to move to another place, called brothel. It is the beginning of her suffering in that place.

\section{d. Domination}

Nepal is a patriarchal country where male dominates female. Men are considered superior as leaders of family, such as being father and husband. The status of Nepalese woman is powerless than the man in society. Domination is the exercise of control or influence over someone or something, or the state of being so controlled (Cambridge Advance Learner's Dictionary). Sold is the representation of Nepal situation which domination is one of social practices in society. The 
domination in this section relates to violence. Gelles and Cornell (1990: 54)state that violence is an act carried out with intentions perceived for causing physical pain or injury to another person. In many parts of Nepal, the crime against women is increasing day by day.

This novel tells about some violences, which happen in the Nepal. Lakshmi as the main character faces violence that is done by two people. Those are the old man, the owner of the brothel and the woman named Mumtaz, a pimp who helps the old man. Those can be seen in the following data.

Datum 30 We are in India now," Uncle Husband has told me. Don't speak to anyone here. If they hear you talk, they will know you're from the mountains and they will try to take advantage of you.

The italic sentence above describes clearly that the old man, the owner of the brothel tries to remove the girl from everything that is familiar. The unfamiliar things can be very scary and can make anyone feel powerless. The sentence of Don't speak to anyone here belongs to prohibition for girl by not to talk to a stranger people. It implies that the man is afraid if someone knows about his illegal job. Lakshmi as a pure girl follows everything he said. While they are going to cross the border, he attempts to convince police officer that she is his wife. He also tries to influence her by saying that the city people are bad. The old man does not only cheat her but also he treats her very bad. The next datum shows how bad the old man and the pimp treat Lakshmi in the brothel.

\section{Gender Inequality Based on the Cognition of Nepal}

The cognition in this term is a mental representation of a certain group of people. Nepalese view that women's position are dominated by male including in the social practice, tradition and other cases. Many women think of their husbands as their God, one who should be worshipped and he should be followed without questions. The tradition of girls going away to their husband's house upon marriage has reduced their status within their own family.

Gender inequality refers to unequal treatment or perceptions of individuals based on their gender. Shastri (2014, p.28) reveals that gender inequality refers to the disparities between women and men based on their gender rather than objective differences in skills, abilities, or other characteristics. Gender basically refers two sexes of men and women. Biologically both are having different roles and some major responsibilities, which they have to fulfill.

Generally, gender inequality word is used for women because they are considered being most inferior and weaker section of Nepal society. Gender inequality is not a very new phenomenon in this modern time in Nepal, but it was also prevailing in the ancient time. Women face every kind of discrimination in this society.

Jha \& Nagar (2015, p.47) classify seven types of gender inequalities in Nepal. Those are mortality inequality, natality inequlity, employment 
inequality, ownership inequality, special opportunity inequality, basic facility inequality, and household inequality. The novel tells about household inequalities that often occurs in Nepal.

\section{Gender Inequality Based on the Social Situation in Nepal}

The social situations have been explained in the previous chapter. It implies the social representation of power, domination and social inequality. The culture of Nepal is represented in the novel entitled Sold. Nepal is one of developing countries in which male dominates female. Woman needs a husband and a family. Their dominating nature has led women to walk with their head down, which applies until now. Nepalese believe that women are born to do household tasks, manage children and family. In addition, there are many gender inequalities, which are found in the novel in term of behaviour and harrasment. It is linked with the data below;

Datum 14 Now, she says, you must carry yourself with modesty, bow your head in the presence of men, and cover yourself with your shawl.

Datum 16 Once you are married, she says, you must eat your meal only after your husband has had his fill. Then you may have what remains.

Datum 17 If your husband asks you to wash his feet, you must do as he says, than put a bit of the water in your mouth.

Data 14,16 , and 17 belong to Nepalese women's behaviour in the social life. The first datum is shown in datum '14. Those phrasesare carry yourself, bow your head in the presence of men, cover yourself with your shawl. They are obvious that women must be able to know how to behave as women while they are not with her family and husband. The phrase of bow your head in the presence of men points that women have to nod their head while they passed in front of men. This kind of body language shows the way women respect men so much. This kind of behaviour is not enough showing respecting men. It is shown in the phraseof cover yourself with your shawl. The phrase reveals that women may not see other men except their own husband while men are able to see woman freely. It figures out the powerless women in Nepal by covering their face with the shawl while they are in front of men.

\section{CONCLUSION}

Nepal is a developing country in which gender inequality is going on in terms of education, health, employment, social values, customs, on the name of caste, as well as on the norm of sexual harassment. Nepal witnessed gender inequality from its early history due to its social, economic and religious practices that resulted a wide gap between the position of men and women in the society. The novel entitled Soldis the representation of Nepalese culture. It tells the story of a girl from Nepal named Laksmi, who is sold into sexual slavery in India.

Gender inequalities are found in the novel by analysing the text, cognition, and the social situation through sentences of the novel. There are three main parts of the text analysis 
used by Van Dijk's theory. They are microstructure, macrostructure, and superstructure. The first text analysis is microstructure. It examines syntax and stylistics to interpreate and understand what the messege of discourse is about. It is classified into verb, phrase, noun, and adjective containing gender inequality between male and female in the novel. The sytlistics of the novel that is used in the novel is implisit to show a conotation to represent of something, which makes the language more polite. The second text analysis is supertructure. It is correlated with schema. The schema of the novel consist of beginning, inciting incident motivating force, complications, climax, anticlimax, and conclusion. The third text analysis is macrostructure. It is a global meaning of text, which can be observed by seeing the theme of discourse. There are four themes, which are found in the novel. Those are poverty, sacrifice, sex trafficking, and domination.

The cognition of the novel is a mental representation. There are two kinds of ways of thinking inthe novel as representation of Nepalese. Those are dowry and sons preference. Giving dowry is a practice of giving money, property, or some kinds of special gifts at the marriage of a daughter by the father to bridegroom or bridegroom's family. Sons preference is that boys are given the exclusive rights to inherit the family name and properties and they are viewed as additional status for their family. Nepalese claimes that if families are lacking a son, they have to find a nephew to perform the funeral rights, a daughter will not do.

The social situation relates to social culture in Nepal containing of gender inequalities in term of behaviour and harrasment. Nepalese girls have to cover herface while she walks alone; they have to wait for their husband whenever they eat. Further, she must receive harrasment in term of jokes.

This article concludes that gender inequality is a crucial problem in developing countries. It needs the awareness of society that gender inequality can be reduced through education. The educated people will never stop struggling in any condition, especially for women. They will not have fear to oppose gender inequality whenever it happens toward herself.

\section{REFERENCES}

Agrawal, T., \&Agrawal, A. (2015). Trends in occupational gender segregation in India. International Journal of Gender Studies in Developing Societies Vol I No 1; Juni 2015.

Anderson, D. (2015). Affirmative Action: A Feminist Economics Policy to Counteract Implicit Bias in Employment.International Journal of Gender and Women Studies Vol.3 No2: 1-11

Blaxter, L., Hughes, Christina., \& Tight, M. (2006). How to Research. Buckingham: Open University Press.

Chandler, D. (2002). Semiotics: The Basics (second edition). London: Routledge. 
Gelles, R.J.,\& Cornell, C.P. (1990) Intimate Violence in Families, 2nd ed., Sage, Newbury ParkHornby, A.S. 1995. Oxford Advance Learner's Dictionary. Oxford: Oxford University Press.

Jha, P.,\& Nagar, P. (2015). AStudy of Gender Inequality in India. The International Journal of Indian Psychology, Volume 2.

Mackey, A.,\& Gass, S.M. (2005). Second Language Research Methodology and Design. New Jersey: Lawrence Erlbaum Associates, Inc.

Mackin, E. (2014). The World Survey on the Role of Women in Development, on the theme of "gender equality and sustainable development. New York: United Nation publication.

McCormick. P. (2006). Sold. New York: Hyperion

Murphy, P. F. (2004). Feminism and Masculinitie. New York: Oxford University Press. Inc.

Dijk, T.A.V.(2001). "Critical Discourse Analysis". In Schriffin, D. Tannen, D. Hamilton, H.E. (Editor). The Handbook of Discourse Analysis. New York: Blackwell Publishers. Ltd.

Dijk, T.A.V.(2009). "Discourse and Cognition in Society". In Society and Discourse. How social contexts control text and talk.Cambridge: Cambridge University Press.

Shastri, A. (2014). Gender Inequlity and Women Discrimination. IOSR Journal Of Humanities And Social Science (IOSR-JHSS), Volume 19: 28.
Wasti, P.S. (2011). In What Way Do Nepalese Cultural Factors Affect Adherence to Antiretroviral Treatment in Nepal. Health Science Journal: Volume 5

Internets:

http://cambridge-advanced-learners-dictionary2.software.informer.com. Retrieved 17 December 2016 https://en.oxforddictionaries.com. Retrieved 17 December 2016 UNICEF (2009) Progress for Children: A Report Card on Child Protection. http://www.end corporalpunishment. org/pages/research/i. Retrieved 16

December 2016). 